\title{
Benefits from the Standardization of the Complaint Management System
}

Chanthaly S.Phabmixay ${ }^{1}$, Ana Isabel Rodríguez-Escudero ${ }^{2}$ and Javier Rodríguez-Pinto ${ }^{3, *}$

Department of Business Management and Marketing, University of Valladolid, Valladolid, Spain

${ }^{1}$ Chanthaly S.Phabmixay

Facultad de Comercio, Plaza Campus Universitario 1, 47011 Valladolid (Spain)

Email: chantaly@emp.uva.es

ORCID ID: 0000-0003-4070-0821

${ }^{2}$ Ana Isabel Rodríguez-Escudero

Facultad de Ciencias Económicas y Empresariales, Avda. Valle Esgueva 6, 47011 Valladolid (Spain)

Email: ana@eco.uva.es

ORCID ID: 0000-0002-8827-5353

${ }^{3}$ Javier Rodríguez-Pinto

Facultad de Ciencias Económicas y Empresariales, Avda. Valle Esgueva 6, 47011 Valladolid (Spain)

Email: javierrp@eco.uva.es

ORCID ID: 0000-0002-9774-3171

* Corresponding author:

Javier Rodríguez-Pinto

Facultad de Ciencias Económicas y Empresariales, Avda. Valle Esgueva 6, 47011 Valladolid (Spain)

Email:javierrp@eco.uva.es

Telephone: +34983184569

Fax: +34983423899

This work was supported by the Junta de Castilla y León (Spain) under Grant VA112P17 and VA085G18, and the Ministerio de Economía, Industria y Competitividad, project reference ECO2017-86628-P. 


\section{Benefits from the Standardization of the Complaint Management System}

This research provides new developments in the conceptualization of the complaint management system by examining the benefits of the standardization of the complaint management process. In line with a mechanistic approach of organizational behaviour, we posit that standardization of complaint handling can help to overcome defensive behaviour by employees and managers, who can view receiving complaints as a decidedly negative experience. Specifically, we investigate the influence of three types of guidelines — procedural, behavioural, and outcome - on achieving fairer solutions for customers and, consequently, greater satisfaction with the system. The model proposed in the present research is tested considering the managers' perspective and using data from a representative sample of manufacturing companies covering multiple industries. Our findings provide novel and interesting insights on the factors to which managers in manufacturing firms should pay closer attention when designing an effective complaint management system. All three types of guidelines help to explain perception of justice in the solution of complaints and, thus, customer satisfaction, but important differences exist for the different types of guidelines and their corresponding dimensions.

Keywords: complaint management system; customer satisfaction; perceived justice; standardization; complaint handling guidelines

\section{Introduction}

Until recent decades, complaint management has not been an organizational area of special interest, neither in the academic nor in the business. However, as markets mature and become increasingly competitive, traditional objectives of offensive marketing, such as attracting new customers and promoting brand change, are becoming harder to achieve. Consequently, companies are motivated to be more purposeful in adopting a defensive commercial strategy that contributes to customer retention. An effective complaint management system is an important part of this strategic focus. However, despite the expected benefits of good 
complaint management system (Goodwin \& Ross 1992, Tax, Brown \& Chandrashekaran, 1998, Smith, Bolton \& Wagner, 1999) and although firms continue to invest in technology, call centres, and staff training (Grainer, Noble, Bitner, \& Broetzmann, 2015), many organizations fail to manage complaints in a way that meets the consumers' expectations (Van Vaerenbergh \& Orsingher, 2016).

This lack of effectiveness in complaint management systems is to a large extent explained by the employees' and managers' defence mechanisms, which cause them to view complaints as an uncomfortable complication rather than an opportunity (Homburg \& Fürst, 2007). Companies commonly seek to psychologically distance themselves from the complaint process. As a result, they do not clearly communicate to their customers where, how, and to whom they can complain and do not identify the true reasons for complaints or analyse complaints data to detect opportunities for improvement. As such, employees' and managers' defensive behaviour creates barriers to the development of an efficient complaint management system.

We propose that one way to overcome this defensive behaviour is to normalise or standardize the complaint handling. The theoretical foundations of our research are in line with the mechanistic approach of organizational behaviour. This approach indicates that a company can improve the behaviour of its members by implementing standards and normalized operating procedures that guide their decisions and actions in line with the organization's objectives (March \& Simon, 1993). Establishing clear guidelines can help employees to act in a more disciplined way and improve their attention to the activities they must carry out on a day-to-day basis (Chebat \& Kollias, 2000).

We research how the standardization of the complaint management system contributes to efficient handling and provide three main contributions to the literature. First, 
we identify and classify the various actions and stages in the complaint handling process to determine whether standardisation can contribute to positive complaint resolution. Although prior literature primarily analyses specific behaviours such as facilitation (Goodwin \& Ross, 1992; Davidow, 2000), punctuality (Morris, 1988; Conlon \& Murray, 1996), personal attention, apology (Smith at al., 1999) or compensation (Davidow, 2000; Estelami, 2000), previous studies do not comprehensively examine all company actions. Table 1 shows that literature on complaint management has addressed certain variables to a considerable extent (e.g., facilitation, timeliness, attentiveness, apology or redress), while ignored or paid too little attention to other variables such as customer participation in the complaint handling process or in the solution. We thus advance knowledge on complaint management by investigating the effect of standardisation throughout the entire complaint handling process.

Second, in our study the proposed model is tested on a representative sample of manufacturing companies covering multiple industries. Such an approach is yet to figure prominently in complaint handling research, which is mainly based on specific industries and the service sector (Vos, Huitema, \& De Lange-Ros, 2008). The inseparability of production and consumption and the greater likelihood of heterogeneity in the provision of services may explain why most research studies have been conducted in service industries. In the area of manufacturing companies, however, far less scholarly research has been conducted into complaint management, despite the fact that for manufacturers of industrial products and consumer products alike, it might be of great interest. In the former case, this is because industrial customers often need a product tailored to their business, which leads to greater diversity in the sales and production processes, in turn increasing the likelihood of failure as it is more difficult to guarantee consistent quality. In the case of consumer product manufacturers, this is because they mostly work with indirect distribution channels 
(Anderson \& Narus, 1990) and, therefore, loose control and are not directly aware of the "voice of end user".

Third, we contribute to the literature by examining the effect of standardising the complaint process from the perspective of managers, not consumers. Table 1 shows that most prior literature focuses on the perspective of consumers. Apart from two notable exceptions (Homburg \& Fürst, 2005; Homburg, Fürst, \& Koschate, 2010), research into complaint handling has mainly been conducted considering the customer perspective only. A consumer can only assess the response the company has given to her/his particular complaint, so she/he will only have an opinion about those aspects of the complaint handling which were relevant in her/his particular case. For instance, there might be cases in which it is not necessary to discuss with the customer which is the best solution because it is obvious. The managers' viewpoint is therefore fundamental so as to make a comprehensive evaluation of the relevance of all the behaviours, actions and stages in the complaint process.

\section{[Table 1 about here]}

In sum, taking the above-mentioned contributions as a reference, in this research we first aim to expand current knowledge on complaint handling by outlining a theoretical model which reflects the importance of considering the effect of standardisation throughout the whole complaint handling process. In other words, we seek to address the lack of attention in prior literature concerning variables that might prove relevant to consumer satisfaction, such as participation in the process and in the solution. In addition to this theoretical approach, other key issues the work seeks to deal with involve testing the proposed model in a representative sample of manufacturers from a range of industries and doing so from the company perspective. To date, neither approach has received much attention in the literature 
on complaints management, which has thus far primarily concerned itself with exploring said phenomenon in service companies and from the standpoint of the consumer.

\section{Theoretical Framework}

As previous discussed, a mechanistic approach suggests that the formalisation of a management structure allows for the clear delineation of tasks, responsibilities, guidelines, and schedules to achieve an effective functioning of the organization (Simon, 1997). Applied to complaint management system field, mechanistic approach involves establishing a formal structure for handling of complaints to achieve fair and fast solutions for the customer. According to Homburg and Fürst (2005), such guidelines can be systematised into three groups: procedural, behavioural and outcome guidelines. Figure 1 illustrates the model.

First, procedural guidelines are defined as the formal organizational structure for recording and processing complaints in a way that is consistent with customers' needs. We understand that these standards range from the availability of different channels for receiving complaints, processing protocol, and possible customer intervention in the complaint process and resolution. Therefore, we consider four types of procedural guidelines: facilitation, processing protocol, customer participation in the process, and customer participation in the solution. We define behavioural guidelines as those that guide employee interactions with customers to use appropriate interpersonal skills and provide relevant information about the complaint. Based on this definition, we consider two dimensions: interpersonal treatment and level of explanation that company gives to customer. The third block is related to the outcome guidelines, which are defined as the tangible and intangible (psychological) compensation the company provides to the customer to remedy the damage caused. The company's explanation, following the appropriate behavioural guidelines, may be insufficient to maintain or recover a positive relationship with the customer. In such case, additional 
redress such as the repair work, change, discount, or reimbursement (Kelley, Hoffman, \& Davis, 1993) in addition to an apology may be necessary to achieve resolution. Thus, we consider two types of outcome guidelines: apology and redress.

Following the mechanistic approach, these guidelines influence the results of the complaint process. Prior literature widely uses the perceived justice in solution of complaints as a variable to determine the effectiveness of corporate responses to customer complaints and as an antecedent to other relevant variables such as repurchase intentions and word of mouth (Conlon \& Murray, 1996; Orshinger, Valentini, \& Angelis, 2010). In this study, justice in solution of complaints construct refers to the justice perceived by customer as a global assessment of the solution provided by the company to solve the problem. Furthermore, because the literature finds that greater perception of justice leads to greater customer satisfaction (Chao \& Cheng, 2017), we include a company satisfaction variable, which is the final result of establishing a good complaint management system (see Figure 1).

In sum, we develop and test a model, first, to determine whether the standardization of the complaint management system influences customers' perception of justice in the solution and, consequently, in their satisfaction with the system, which ultimately leads to greater company satisfaction. Second, we examine the relevance of each guideline type (procedural, behavioural, and outcome) in explaining the fairness of solutions. Some of these guidelines, although necessary for organizational purposes, may not be a specific source of consumer satisfaction but, instead, may be merely a necessary condition.

Along with the main relationships, Figure 1 shows the direct effects of the mechanistic approach on customer satisfaction as control relationships. That is, we investigate what types of norms are a source of satisfaction beyond the customer's perception of a fair solution. We also control for the effect of organic approach on the three variables of 
results of the complaint management system. The organic approach is based on the creation of a supportive climate which fosters greater commitment to satisfying customer needs, and leads to a better alignment of employees' motivations and behaviours with the internal and external demands. The inclusion of this control relationship allows us to determine the extent to which the mechanistic explanation maintains its relevance in the presence of this variable.

[Figure 1 about here]

\section{Hypotheses Development}

\section{Benefits from Procedural Guidelines}

Within procedural guidelines, facilitation refers to the policies, procedures, and structure that a company establishes to simplify the process of filing a complaint by customers (Davidow, 2003). Customers can interpret this facilitation as a proof of the company's support and willingness to solve any conflict that arises in business relationship between both parties. When the company provides adequate information to customers about how and where to file a complaint and makes available accessible and user-friendly reception channels, the company increases customers' perception of justice in the solution to complaints. Goodwin \& Ross (1992) and Davidow \& Leigh (1998) confirm that facilitation has a positive effect on a customer's level of satisfaction in the handling of a complaint. Therefore, we state our first hypothesis:

$\mathbf{H}_{1}$ : Facilitating the presentation of complaints has a positive influence on perceived justice in solutions.

When a company has an internal protocol process for the registration of complaints that include the classification of the complaint according to origin and severity, assignment of 
a person responsible for its management, and confirmation to customer about the initiation of the resolution process, the customer is more likely to perceive that the company diligently attempting to solve the problem. Homburg \& Fürst $(2005,2010)$ show that the quality of the norms established by the company for the complaint management process positively affect customers' evaluations. Accordingly, we posit that the existence of a well-defined protocol of action by the organization, with an adequate allocation of tasks and responsible personnel for its implementation, can improve customers' perception of justice to the extent that a competent and user-friendly complaint management system conveys a sense of security and confidence to customers. Conversely, procedures that are inconsistent or arbitrary, especially those that cause disruption to the customer, can contribute to a higher cost for customers and lower their assessment of justice (Tax et al. 1998). Given this discussion, we state our next hypothesis:

$\mathbf{H}_{2}$ : A well-defined processing protocol for handling complaints has a positive influence on perceived justice in solutions.

Customer participation in the process refers to the opportunities the company offers to the customer to explain a complaint; in other words, the company's efforts to hear the origin and details of the complaint from the customer's point of view (Tax et al., 1998; Smith, Karwan, \& Markland, 2009). The ability to explain the problem increases customers' positive perception of process control, which can, in turn, positively influence customers' level of satisfaction and commitment to company (Lind \& Tyler, 1988; Goodwin \& Ross, 1992). Individuals accept decisions better when they feel that they control the processes (Saxby, Tat, \& Johansen, 2000). Therefore, two-way communication, which encourages involvement by the customer and active listening by the company, can increase customers' perception of justice in the complaint management process. Given this discussion, we posit that the more 
the company understands about the specific situation of each complaint and customer, through active participation by both the customer and the company, the more likely customers are to consider the resolution as fair. Therefore, we propose our next hypothesis:

$\mathbf{H}_{3}$ : Enabling customers to participate in the complaint handling process has a positive influence on perceived justice in solutions.

Customer participation in the solution are based on the opportunities that the company provides customers to work together in search for a solution that takes into account customers' needs and desires (Tax et al., 1998; Smith et al., 2009). Saxby et al. (2000) find that customer participation in the solution affects customers' acceptance or rejection of the company's decisions in resolving the problem. Providing avenues of participation to customers to actively engage in reaching a jointly satisfactory solution requires the company to be flexible and adapt the procedures according to the individual circumstances of each complaint. This flexibility by the company is linked to a market orientation that leads to greater customer satisfaction (Narver \& Slater, 1990; Tax et al., 1998; Smith et al., 1999). Consequently, we state the following hypothesis:

$\mathbf{H}_{4}$ : Enabling customers to participate in the complaint solution has a positive influence on perceived justice in solutions.

\section{Benefits from Behavioural Guidelines}

From a management perspective, prior research highlights the importance of interpersonal relationships. Previous research identifies key aspects of this dimension including respect, empathy, honesty, and tone (Morris, 1988; 2003) and explains the effect of interpersonal communication on satisfaction, repurchase intentions, and recommendations (Blodgett, Hill, \& Tax, 1997; Estelami, 2000; McCollough, Berry, \& Yadav, 2000; Davidow, 2000, 2003). 
Empirical results show that the way in which employees interact with customers significantly influences customers' behaviour after the complaint, especially satisfaction and repurchase actions. Alternatively, the lack of consideration of interaction factors can explain why some customers feel unfairly treated even though they receive fair compensation (Bies \& Shapiro, 1987). Therefore, we state the following hypothesis:

\section{$\mathbf{H}_{5}$ : Providing good interpersonal treatment to customers has a positive influence on perceived justice in solutions.}

The complaint management literature, in general, concurs a company's explanation of a complaint plays a key role in retaining or restoring customer trust and the company's credibility (Davidow, 2003). When the explanation allows customer to understand that the problem is not normal but rather exceptional, the company is more likely to recover from its error (Blodgett et al., 1997). Even when the problem can be directly attributed to the company, providing a full explanation and acknowledging fault is better than avoiding responsibility or blaming others. Acknowledging fault is a sign of transparency that positively affects customers' perceptions, especially if the company also clarify the steps it will take to prevent similar failures (Bitner, Booms, \& Tetreault, 1990; Conlon \& Murray, 1996; Boshoff \& Leong, 1998; Davidow 2003). In short, we posit that the level of explanation given by company to a customer that lodges a complaint is related to the perception of justice in the solution of complaint based on the company's transparency and willingness to respond to customers' questions and wishes. Therefore, we propose the following hypothesis:

\section{$\mathbf{H}_{6}$ : Properly explaining the causes of the complaints has a positive influence on} perceived justice in solutions. 


\section{Benefits from Outcome Guidelines}

Davidow (2003) argues that an apology does not cost anything. However, companies commonly do not offer unsatisfied customers an apology, even when doing so may reduce a customer's anger caused by a company error. In fact, in some cases, an apology may itself be the solution to problem, especially in less critical situations (Webster \& Sundaram, 1998). An apology does not necessarily imply admission of guilt by company (Goodman, Malech, \& Boyd, 1987). Even when a firm does not claim fault for the problem, an apology can be a good answer. Apologizing is a way of externalizing and making visible that the company considers the customer's complaint as legitimate, that it understands the reasons for the customer's dissatisfaction and the seriousness of the problem, and that it will do its best to find a solution (Davidow, 2003). In short, by apologizing, the company provides psychological compensation to customers by acknowledging the problem and affirming a sincere desire to reach a satisfactory resolution. As such, apologizing can increase the customer's perception of justice in the solution of the complaint (Smith et al., 1999). Therefore, we state the following hypothesis:

\section{$\mathbf{H}_{7}$ : Apologizing for the complaints has a positive influence on perceived justice in solutions.}

We define redress as any additional economic reward beyond the solution of the problem. Redress may increase the customer's perceived value of the resolution, particularly when the problem is the fault of the company (e.g., inadequate management) and caused the customer to be inconvenienced (Hoffman, Kelley, \& Rotalsky, 1995; Davidow, 2003). Offering more than what customer expects to compensate for a bad experience in the business relationship can increase the customer's sense of equity (Hess, Ganesan, \& Klein, 2003; Kwon \& Jang, 2012). Granting such compensation reinforces the company's credibility 
and commitment to the customer, and thus redress helps to increase the level of customer satisfaction and positively favours their behavioural intentions after the complaint (VázquezCasielles, Iglesias-Argüelles, \& Valera-Neira, 2012). Therefore, we state the following hypothesis:

\section{$\mathbf{H}_{8}$ : Redressing customers for the complaints has a positive influence on perceived justice in solutions.}

\section{Method}

Our population universe includes 2,536 Spanish companies with more than 50 employees from different manufacturing sectors (Amadeus database). We require a minimum of 50 employees for a company to be included because smaller companies may have more difficulty establishing a standardised procedure and to provide information on certain variables in the model. For data collection, we use a questionnaire, which was pretested with five manufacturing industry managers as well as the head of the contact centre division of an integral marketing services company. The questionnaire was sent to all the companies in the population universe together with a cover letter explaining the study and a website address for those who preferred to fill out the questionnaire online. The cover letter was addressed to the marketing manager, although it requested that the head of complaint handling at the company complete the questionnaire. After making roughly 900 phone calls to urge participation, we received 140 valid surveys.

To assess sample representativeness, we use two variables: industry type and number of employees. Regarding the industry, the proportion test reveals no significant differences, suggesting that the composition of the sample is similar to the population we are surveying. Table 2 shows a summary of the population and industry distribution. In addition, a means 
test verifies that the number of employees in sample companies does not differ significantly from the average of the population. This finding holds for each industry, with the exception of the group of companies competing in chemical, natural rubber, and plastic materials industries ${ }^{1}$. Overall, we find that the sample is representative of the population of companies whose complaint handling behaviour we seek to study.

\section{[Table 2 about here]}

Given that in each company a single informant answered all the survey questions, steps were taken to ensure that common method bias (CMB) is not an important issue in this investigation. Following Podsakoff, Mackenzie, Lee \& Podsakoff's (2003) recommendation, an effort was made a priori to reduce common method variance (CMV) through careful design of the questionnaire wherein item wording was thoroughly revised so as to prevent biased connotations and where the order of the questions was dissimilar to the sequence of cause-effect relationships specified in the model. In addition, we apply Harman's one-factor test and find that our data do not have a large amount of common method variance. According to Fuller, Simmering, Atinc, Atinc \& Babin (2016), the results of this test indicate that a large amount of CMV is not observed in our data and, what is more important, it is therefore very unlikely that common method could substantially bias the estimated relationships.

\footnotetext{
${ }^{1}$ For this group of industries, firms in our sample have a significantly larger workforce. However, our sample includes the company that employs, by far, the largest workforce of all those in these industries. The addition of this company obviously dramatically increases the average number of employees in the sample. Excluding this company, the average number of employees in the sample falls to 192, with a standard deviation of 298 ( $z$ statistic $=-0.40)$, which leads us to conclude that the companies in our sample in these sectors do not significantly differ in size from the population they represent.
} 
Because the literature primarily approaches the topic from the customer's perspective, we had to make major adaptions to prior scales. Specifically, we based our instruments on the scales proposed by Tax et al. (1998), Smith et al. (1999) and Homburg \& Fürst (2005). We used seven-point Likert scales from 1 (disagreement) to 7 (agreement). Table 3 shows the items used for the measurement of the constructs in our model. The mechanistic approach variables are measured as reflective scales, except for facilitation and processing protocol, which are operationalized as formative indices. The organic approach, introduced as a control variable, is operationalized as a second-order reflective-formative construct. The first-order reflective components are employee training, empowerment, and extra-role behaviours (Hartline \& Ferrell, 1996; Homburg \& Fürst, 2005; Chan \& Lam, 2011), which cause the second-order formative index that we have called organic approach.

[Table 3 about here]

\section{Results}

To test our model, we employ partial least squares path modelling using SmartPLS v.3.2.8 (Ringle, Wende, \& Becker, 2015) software. We select partial least squares path modelling, since this technique allows for work with modest sample sizes and enables us to estimate relatively complex models that simultaneously include reflective and formative constructs, as is our case. We analyse and interpret the results of our tests in two phases: evaluation of the reliability and validity of the measurement model and evaluation of the structural model (Hair, Hult, Ringle, \& Sarstedt, 2014).

Table 3 shows the main magnitudes of the measurement model of our variables. For the validation of the reflective scales, literature recommends that the factor loading be higher than 0.7 , composite reliability above 0.7 , and the variance extracted above 0.5 (Hair et al., 
2014). Our reflective scales meet these conditions. To validate the formative indices, we analyse the size and significance of the weights of each indicator once tested that there are not multicollinearity problems. Regarding the reduced weight and the lack of significance of some items corresponding to the facilitation and processing protocol variables, we maintain these indicators due to their contribution or absolute importance; that is, the information they provide without considering the other indicators of the construct is moderately elevated (the factor loadings of these items are close to 0.5). The correlations between each pair of indicators are less than 0.7 , and the variance inflation factor is below the threshold of 5 . Finally, discriminant validity is evaluated for the set of variables using Fornell \& Larcker's (1981) procedure and the application of the heterotrait-monotrait ratio (Henseler, Ringle, \& Sarstedt, 2015). Table 4 confirms discriminant validity.

\section{[Table 4 about here]}

Table 5 shows the effects resulting from the structural model estimation. Prior to commenting the results of hypotheses testing, it should be noted that perceived justice in solution is positively related to customer satisfaction $(\beta=0.36, p<0.01)$, which in turn has a strong positive effect on company satisfaction with the complaint management system $(\beta=$ $0.56, p<0.01)$. Therefore, in addition to examining the hypothesized direct effects of the mechanistic approach variables on justice in solutions, relevant indirect effects on customer and company satisfaction will also be reported.

In relation to the hypotheses that propose a positive effect of procedural guidelines on customer perceived justice, the effects of facilitation and processing protocol on perceived justice are not significant; therefore, the results do not support $\mathrm{H}_{1}$ and $\mathrm{H}_{2}$, respectively. Likewise, we find that facilitation and processing protocol are not related, neither directly nor indirectly, with customer satisfaction or company satisfaction. Thus, these two procedural 
guideline dimensions apparently do not significantly influence the results of the complaint management system.

\section{[Table 5 about here]}

Table 5 shows that the other two dimensions of the procedural guideline, customer participation in the process $(\beta=0.22, p<0.05)$ and the search for a solution $(\beta=0.14, p<$ 0.05) positively influence customers' perception of justice. These results, therefore, support $\mathrm{H}_{3}$ and $\mathrm{H}_{4}$, respectively. In addition, customer participation in the solution has a direct effect on customers' level of satisfaction $(\beta=0.22, p<0.05)$. This positive direct effect adds up to the indirect effect (via greater justice). Thus, findings indicate that allowing customers to participate in finding a solution to the problems they complain about is more effective to recover customer satisfaction than other procedural guidelines (the total effect of customer participation in the solution on satisfaction is $0.27, p<0.05)$. In turn, procedural guidelines related to customer participation in the solution positively contribute to a greater company's satisfaction with the complaint management system (total effect $=0.15, p<0.05)$.

Related to the behavioural guidelines hypotheses, Table 5 shows that interpersonal treatment does not significantly influence perceived justice $\left(\beta=0.10\right.$, n.s.). Therefore, $\mathrm{H}_{5}$ is not supported. Conversely, the level of explanation positively influences the perception of justice, thus supporting $\mathrm{H}_{6}(\beta=0.32, p<0.01)$. In addition, the level of explanation considerably influences customer satisfaction indirectly (indirect effect $=0.11, p<0.05$ ), which in turn translates into a greater company satisfaction (total effect $=0.15, p<0.05$ ).

The results for the outcome guidelines on perceived justice show a significant positive direct effect of the apology $(\beta=0.28, p<0.01)$; therefore, $\mathrm{H}_{7}$ is supported. In addition, the influence exerted by apologizing has an indirect effect, through perceived justice, on customer satisfaction $(0.10, p<0.01)$ and on company satisfaction (total effect $=0.13, p$ 
$<0.05)$. Unexpectedly, redress is negatively and significantly related to customers' perception of justice $(\beta=-0.12, p<0.05)$. Consequently, $\mathrm{H}_{8}$ is not supported. Redress has no significant effect on the other result variables, customer satisfaction and company satisfaction.

\section{Discussion}

Both academic and business literature addressing complaint management reveal that how organisations respond to customers' complaints is key to securing satisfaction goals (Davidow, 2003; Homburg \& Fürst, 2005). In this vein, the findings derived from our study indicate that standardising company responses has a positive impact on customers' perceived justice and subsequent satisfaction with the complaint handling system. The mechanistic approach in the complaint system plays a decisive role in explaining consumer perception of justice and satisfaction.

Specifically, our findings indicate that three types of guidelines (procedural, behavioural, and outcome) help to explain perception of justice in the solution of complaints and, thus, customer satisfaction with the complaint management system. However, important differences exist for the different types of guidelines and their corresponding dimensions.

The results for the procedural guideline show that the facilitation of the customer's voice and the establishment of a processing protocol do not significantly influence perceived justice. In other words, to explain justice is more important to ensure customers can participate in the process and in the solution than the mere fact of facilitating customers to submit their complaints or setting up an agile and standardised processing protocol. However, this lack of effect can be explained by the high correlations between the four procedural variables. Thus, the findings do not suggest a lack of relevance for the facilitation and the 
processing protocols in determining the degree of perceived justice; rather, both types of action may be considered necessary, but not sufficient, conditions.

The results of the dimensions of the behavioural guideline (interpersonal treatment and explanation) show a similar relation. Although the level of explanation has a direct influence on perceived justice and an indirect on customer satisfaction, employees' interpersonal interactions with customers seems to be an irrelevant factor. This result contradicts some prior studies (e.g., Blodgett et al., 1997, Estelami 2000, McCollough et al., 2000). Again, the lack of significance of the effects of interpersonal treatment suggests that its importance of this variable is lower than that of the level of explanation. However, given that the correlations between treatment and explanation are high, we could conclude that the two variables jointly influence perceived justice. In other words, friendly and empathetic treatment of the customer that conveys concern for the problem has real meaning in the explanation of why the failure occurred and the plan for its resolution. However, cordial treatment that lacks content relevant to the complaint and its potential resolution has a practically null effect on customers' perception of justice.

Regarding the outcome guidelines, the explanatory power of an apology is particularly highlighted. An apology shows that the firm regrets the problem caused, whether or not it is actually responsible for it, which might serve to lessen customer anger. In less serious situations, it might even prove to be the actual solution to the problem. Whether or not it is accompanied by reparation of the damage, apologizing not only directly influences justice but also indirectly influences both customer and company satisfaction. That is, apologizing has a positive effect on all three outcome variables considered in this research.

Interestingly, and contrary to our expectations, the effect of redress on perceived justice is significant but negative. Redress as a means of conveying to the consumer the 
message that the firm is the one to suffer the negative consequences of the problem, or that it assumes at least part of the losses caused to the customer, does not work. The explanation for this finding may be that customers perceive redress as a way for companies to quickly remedy an injustice or mistake without either fully explaining the problem or providing reassurances that it will not reoccur. Consequently, redress alone cannot replace good management of the complaint system.

The findings confirm the influence of perceived justice in solutions on customer satisfaction and show the mediating role assumed by perceived justice in the relation between the mechanistic approach variables and customer satisfaction. Likewise, customer satisfaction with complaint management, as expected, is a significant antecedent of the company's satisfaction with the complaint system.

\section{Managerial Implications}

This study shows that all three types of guidelines (procedural, behavioural, and outcome) are important for the effective management of unsatisfied customers and the achievement a solution that the customer perceives as fair. In this regard, we recommend that the management of the complaint system address all three aspects: formalise the procedure for filing the complaint, provide customers with relevant interpersonal communication, and establish clear guidelines for resolution.

Of particular importance is customers' participation in the process (i.e., provide an opportunity for customers to fully express their point of view on the incident) and in the solution (i.e., asking for customers' opinion on how best to reach a solution and repair the relationship). Allowing customers to contribute to the solution to their problems is doubly beneficial, as it not only increases their perception of a fair outcome but also has a significant 
and direct effect on customer satisfaction. Customers who are allowed to contribute their suggestions to the resolution of the problem may interpret the company's willingness to hear them as sign of respect and consideration. As such, they are more likely to evaluate the complaint handling positively even if the final solution itself is not entirely satisfactory. The facilitation and the processing protocol are relevant because, despite these two variables do not per se guarantee a greater perceived justice, a company cannot effectively normalise customer participation in the process and the solution without providing relevant and userfriendly channels for complaint submission and ensures an agile protocol. Consequently, we advise companies to be proactive and provide a helpful and responsive system for customers' to address a problem.

Regarding the behavioural guidelines, we recommend that companies establish behavioural patterns so employees respond with kindness and empathy and, above all, provide customers a full and relevant explanation of the incident. The level of explanation is directly related to satisfaction. That is, clearly explaining the problem and possible solutions increases a customer's satisfaction with the complaint process even when the final solution is not totally satisfactory. Customers' appreciate the company's transparency and its willingness to explain the causes of the problem in a clear manner using understandable language.

Finally, apologizing and, if appropriate, acknowledging the error is inescapably important in achieving customer compliance. However, redress is less effective in resolving complaints because it does not contribute to customers' perception of a fair outcome and thus does not restore their confidence in the company. In fact, the customer may interpret redress unfavourably, viewing more as an unprofessional departure and even a kind of bribe by the company in attempt to compensate for the error without making the effort to achieve an equitable and honest solution. To understand consumers' reactions to the economic compensation granted by the company, companies should consider their own moral 
judgments regarding fault, which are likely to moderate the impact of such compensation in subsequent results (Chen, Ma, Bian, Zheng, \& Devlin, 2018).

\section{Limitations and Future Research Lines}

Despite our efforts to develop a study that takes into account relevant contributions, we acknowledge some limitations that affect our research. First, due to increased complexity, we do not take into account the role played by certain situational variables such as, among others, the variability in the type of problems addressed by customers' complaints, the severity of the complaints, the type of product involved in the complaint, the attribution of responsibility, and the intensity of the commercial relationship between the customer and the supplier. These variables may have a moderating effect on the proposed relationships, and, therefore, their absence should be cited as a limitation when drawing conclusions. Also, due to concerns of increasing complexity of the model, we do not address the possible effects of the interaction between the mechanistic and organic approaches, which could theoretically be proposed. Even though mechanistic and organic approaches imply two different conceptions of how customer complaints and grievances can be handled more effectively, both approaches should be seen as complementary rather than as alternatives. In any case, important lines of research are open to us.

Similarly, future research into complaint handling might benefit from exploring the possible causal relations between various norms from the mechanistic approach. For instance, consumer participation in finding a solution to the complaint lodged by the client and a sound explanation as to why the problem arose might help to ensure that financial redress is not seen as an easy and low involvement way out for the firm. Likewise, positing facilitation as an antecedent of customer participation in the complaint solving process should be considered. Specifically, it is worth exploring whether online channels for receiving 
complaints, in addition to facilitating presentation, might also help customers themselves to provide solutions to the problem and, thereby, increase perceived justice.

Another limitation of this study is related to the form of information collection. The measurement of the model variables uses a single informant: the company manager with responsibility for issues related to the handling of complaints. The use of multiple informants-for example, other members of the company such as other employees themselves as well as the customers - can help to avoid common method biases. Although we do not totally rule out the possibility of common method bias in the sample, our data show no evidence of its presence. Specifically, we observe sufficient discriminant validity and construct correlations which in most instances are moderate. Moreover, we applied Harman's one-factor test and found that it is very unlikely that common method could substantially bias our estimations (see method section). Nevertheless, in light of this limitation we wonder whether customers really do find that the least important variables when gauging perceived justice or determining their degree of satisfaction are facilitation, processing protocol, and redress. Future research from the consumer perspective should test whether the importance attributed by customers to the variables we use to characterise the mechanistic approach of the company's complaint management system coincides with the findings of this study.

\section{References}

Anderson, J. C., \& Narus, J. A. (1990). A model of distributor firm and manufacturer firm working partnerships. Journal of Marketing, 54(1), 42-58.

Bies, R. J., \& Shapiro, D. L. (1987). Interactional fairness judgments: The influence of causal accounts. Social Justice Research, 1, 199-218. 
Bitner, M. J., Booms, B. H., \& Tetreault, M. S. (1990). The service encounter: diagnosing favorable and unfavorable incidents. Journal of Marketing, 54(January), 71-84.

Blodgett, J. G., Hill, D. J., \& Tax, S. S. (1997). The effects of distributive, procedural, and interactional justice on postcomplaint behavior. Journal of Retailing, 73(2), 185-210.

Boshoff, C., \& Leong, J. (1998). Empowerment, attribution and apologising as dimensions of service recovery: An experimental study. International Journal of Service Industry Management, 9(1), 24-47.

Chan, K. W., \& Lam, W. (2011). The trade-off of servicing empowerment on employees' service performance: examining the underlying motivation and workload mechanisms. Journal of the Academy of Marketing Science, 39(4), 609-628.

Chao, C. M., \& Cheng, B. W. (2017). Does service recovery affect satisfaction and loyalty? An empirical study of medical device suppliers. Total Quality Management \& Business Excellence, DOI: 10.1080/14783363.2017.1369351.

Chebat, J. C., \& Kollias, P. (2000). The Impact of empowerment on customer contact employees' roles in service organizations. Journal of Service Research, 3(1), 66-81.

Chen, T., k. Ma, K., Bian, X., Zheng, C., \& Devlin, J. (2018). Is high recovery more effective than expected recovery in addressing service failure? A moral judgment perspective. Journal of Business Research, 82, 1-9.

Conlon, D. E., \& Murray, N. M. (1996). Customer perceptions of corporate responses to product complaints: the role of explanations. Academy of Management Journal, 39(4), $1040-1056$.

Davidow, M. (2000). The bottom line impact of organizational responses to customer complaints. Journal of Hospitality \&Tourism Research, 24(4), 473-490.

Davidow, M. (2003). Organizational responses to customer complaints: what works and what doesn't. Journal of Service Research, 5(3), 225-250. 
Davidow, M., \& Leigh, J. (1998). The effects of organizational complaint responses on consumer satisfaction, word of mouth activity and repurchase intentions. Journal of Consumer Satisfaction, Dissatisfaction and Complaining Behavior, 11, 91-102.

Estelami, H. (2000). Competitive and procedural determinants of delight and disappointment in consumer complaint outcomes. Journal of Service Research, 2(3), 285-300.

Fornell, C., \& Larcker, D. F. (1981). Evaluating structural equation models with unobservable variables and measurement error. Journal of Marketing Research, 18(February), 39-50.

Fuller, C.M., Simmering, M.J., Atinc, G., Atinc, Y., \& Babin, B.J. (2016). Common methods variance detection in business research. Journal of Business Research, 69, 31923198.

Goodman, J. A., Malech, A., \& Boyd, S. (1987). Danger, angry customer. ABA Banking Journal, 79(1), 63-66.

Goodwin, C., \& Ross, I. (1992). Consumer responses to service failures: Influence of procedural and interactional fairness perceptions. Journal of Business Research, 25(2), 149-63.

Grainer, M., Noble, C. H., Bitner, M. J., \& Broetzmann, S. M. (2014). What unhappy customers want. MIT Sloan Management Review, 55(3).

Hair, J. F., Hult, G. T. M., Ringle, C. M., \& Sarstedt, M. (2014). A primer on partial least squares structural equation modelling (PLS-SEM). Thousand Oaks, CA: Sage.

Hartline, M. D., \& Ferrell, O. C. (1996). The management of customer-contact service employees: An empirical investigation. Journal of Marketing, 60(October), 52-70.

Henseler, J., Ringle, C. M., \& Sarstedt, M. (2015). A new criterion for assessing discriminant validity in variance-based structural equation modelling. Journal of the Academy of Marketing Science, 43(1), 115-135. 
Hess, R. L., Ganesan, S., \& Klein, N. M. (2003). Service failure and recovery: the impact of relationship factors on customer satisfaction. Journal of the Academy of Marketing Science, 31(2), 127-145.

Hoffman, K. D., Kelley, S. W., \& Rotalsky, H. M. (1995). Tracking service failures and employee recovery efforts. Journal of Services Marketing, 9(2), 49-61.

Homburg, C., \& Fürst, A. (2005). How organizational complaint handling drives customer loyalty: And analysis of the mechanistic and the organic approach. Journal of Marketing, 69(July), 95-114.

Homburg, C., \& Fürst, A. (2007). See no evil, hear no evil, speak no evil: a study of defensive organizational behaviour towards customer complaints. Journal of the Academy Marketing Science, 35, 523-536.

Homburg, C., Fürst, A., \& Koschate, N. (2010). On the importance of complaint handling design: a multi-level analysis of the impact in specific complaint situations. Journal of the Academy Marketing Science, 38, 265-87.

Kelley, S. W., Hoffman, K. D., \& Davis, M. A. (1993). A typology of retail failures and recoveries. Journal of Retailing, 69(4), 429-52.

Kwon, S., \& Jang, S. S. (2012). Effects of compensation for service recovery: From the equity theory perspective. International Journal of Hospitality Management, 31(4), $1235-1243$.

Lind, E. A., \& Tyler, T. R. (1988). The social psychology of procedural justice, New York: Plenum.

March, J. G., \& Simon, H. A. (1993). Organizations (2nd ed.). Cambridge, MA: Blackwell.

Martin, C. L., \& Smart, D. T. (1994). Consumer experiences calling toll-free corporate hotlines. Journal of Business Communications, 31(3), 195-212. 
Maxham III, J. G., \& Netemeyer, R. G. (2003). Firms reap what they sow: The effects of shared values and perceived organizational justice on customers' evaluations of complaint handling. Journal of Marketing, 67(January), 46-62.

McCollough, M.A., Berry, L. L., \& Yadav, M. S. (2000). An empirical investigation of customer satisfaction after service failure and recovery. Journal of Service Research, $3(2), 121-37$.

Morris, S. V. (1988). How many lost customers have you won back today? An aggressive approach to complaint handling in the hotel industry. Journal of Consumer Satisfaction, Dissatisfaction and Complaining Behavior, 1, 86-92.

Narver, J. C., \& Slater, S. F. (1990). The effect of market orientation on business profitability. Journal of Marketing, 54(October), 20-35.

Orsingher, C., Valentini, S., \& Angelis, M. De (2010). A meta-analysis of satisfaction with complaint handling in services. Journal of the Academy of Marketing Science, 38(2), $169-186$.

Podsakoff, P. M., Mackenzie, S. B., Lee, J. Y., \& Podsakoff, J. O. (2003). Common method bias in behavioral research: A critical review of the literature and recommended remedies. Journal of Applied Psychology, 88(5), 879-903.

Ringle, C. M., Wende, S, \& Becker, J. M. (2015): SmartPLS 3. Bönningstedt: SmartPLS $\mathrm{GmbH}$.

Saxby, C. L., Tat, P. K., \& Johansen, J. T. (2000). Measuring consumer perceptions of procedural justice in a complaint context. Journal of Consumer Affairs, 34(2), 204225.

Smith, A. K., Bolton, R. N., \& Wagner, J. (1999). A model of customer satisfaction with service encounters involving failure and recovery. Journal of Marketing Research, 36(August), 356-372. 
Smith, J. S., Karwan, K. R., \& Markland, R. E. (2009). An empirical examination of the structural dimensions of the service recovery system. Decision Sciences, 40(1), 165186.

Tax, S. S., \& Brown, S. W. (1998). Recovering and learning from service failure. Sloan Management Review, 40(1), 75-88.

Van Vaerenberg, Y., \& Orsingher, C. (2016). Service recovery: An integrative framework and research agenda. The Academy of Management Perspectives, 30(3), 328-346.

Vázquez-Casielles, R., Iglesias-Argüelles, V., \& Varela-Neira, C. (2012). Service recovery, satisfaction and behaviour intentions: analysis of compensation and social comparison communication strategies. The Service Industries Journal, 32(1), 83-103.

Vos, J. F. J., Huitema, G. B., \& De Lange-Ros, E. (2008). How Organisations can Learn from Complaints. TQM Journal, 20(1), 8-17.

Webster, C., \& Sundaram, D. S. (1998). Service Consumption Criticality in Failure Recovery. Journal of Business Research, 41(February), 153-159.

Yilmaz, C., Varnali, K., \& Kasnakoglu, B. T. (2016). How do firms benefit from customer complaints? Journal of Business Research, 69(2), 944-955. 
FIGURE 1

Proposed model

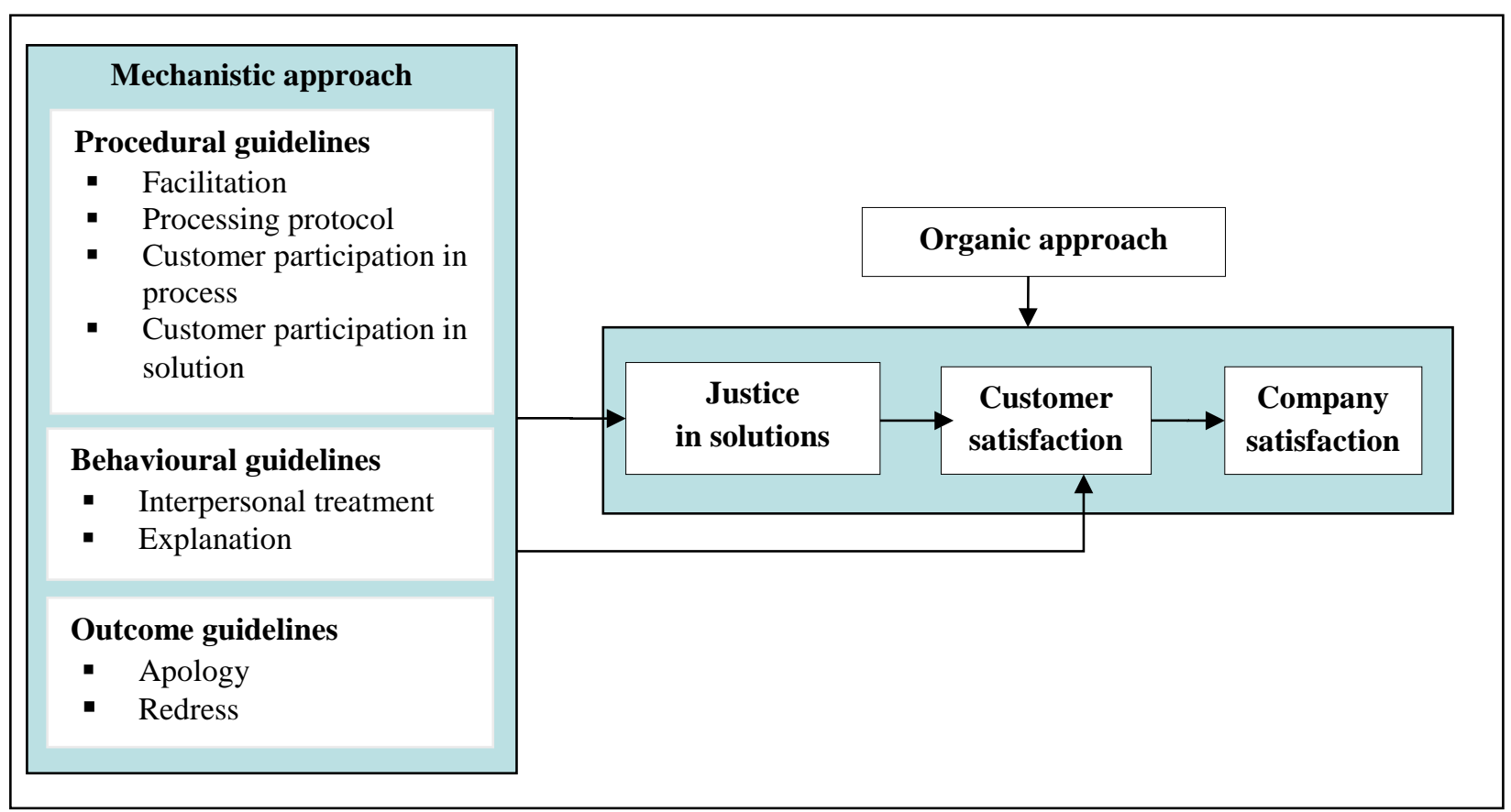

Adapted from Tax et al. (1998), Davidow (2003), Maxham \& Netemeyer (2003), Homburg \& Fürst (2005), and Homburg et al. (2010). 
TABLE 1

Selected studies based on the mechanistic approach

\begin{tabular}{|c|c|c|c|c|c|c|}
\hline Study & $\begin{array}{c}\text { Process } \\
\text { guidelines }\end{array}$ & $\begin{array}{c}\text { Behavioural } \\
\text { guidelines }\end{array}$ & $\begin{array}{l}\text { Outcomes } \\
\text { guidelines }\end{array}$ & $\begin{array}{c}\text { Dependent } \\
\text { Variable }\end{array}$ & $\begin{array}{c}\text { Type } \\
\text { of industry }\end{array}$ & $\begin{array}{c}\text { Information } \\
\text { resource } \\
\end{array}$ \\
\hline $\begin{array}{l}\text { Fornell } \\
\text { \&Wernefelt } \\
(1988)\end{array}$ & Facilitation & & Redress & Repurchase & & \\
\hline Morris (1988) & Timeliness & $\begin{array}{l}\text { Credibility } \\
\text { Attentiveness }\end{array}$ & & $\begin{array}{l}\text { Satisfaction } \\
\text { Word of mouth } \\
\text { Repurchase }\end{array}$ & Services & Customers \\
\hline $\begin{array}{l}\text { Goodwin \& } \\
\text { Ross (1992) }\end{array}$ & Facilitation & & $\begin{array}{l}\text { Redress } \\
\text { Apology }\end{array}$ & Satisfaction & Services & Customers \\
\hline $\begin{array}{l}\text { Martin \& Smart } \\
(1994)\end{array}$ & & $\begin{array}{l}\text { Credibility } \\
\text { Attentiveness }\end{array}$ & Apology & $\begin{array}{l}\text { Satisfaction } \\
\text { Repurchase }\end{array}$ & Services & Customers \\
\hline $\begin{array}{l}\text { Conlon \& } \\
\text { Murray (1996) }\end{array}$ & Timeliness & $\begin{array}{l}\text { Type of } \\
\text { explanation } \\
\text { (excuses, } \\
\text { apology, } \\
\text { justifications) }\end{array}$ & $\begin{array}{l}\text { Presence/absence } \\
\text { of coupons }\end{array}$ & $\begin{array}{l}\text { Satisfaction } \\
\text { Repurchase }\end{array}$ & Products & $\begin{array}{l}\text { Customers } \\
\text {. }\end{array}$ \\
\hline $\begin{array}{l}\text { Tax, Brown \& } \\
\text { Chandrashekan } \\
\text { (1998) }\end{array}$ & $\begin{array}{l}\text { Procedural } \\
\text { justice } \\
\text {-Process control } \\
\text {-Decision } \\
\text { control } \\
\text {-Accessibility } \\
\text {-Timing/speed } \\
\text {-Flexibility }\end{array}$ & $\begin{array}{l}\text { Interactional } \\
\text { justice } \\
- \\
\text { Explanation/caus } \\
\text { al } \\
\text {-Account } \\
\text {-Honesty } \\
\text {-Politeness } \\
\text {-Effort } \\
\text {-Empathy }\end{array}$ & $\begin{array}{l}\text { Distributive } \\
\text { justice } \\
\text {-Equity } \\
\text {-Equality } \\
\text {-Need }\end{array}$ & $\begin{array}{l}\text { Satisfaction } \\
\text { Trust } \\
\text { Commitment }\end{array}$ & Services & Customers \\
\hline $\begin{array}{l}\text { Smith, Bolton } \\
\text { \& Wagner } \\
\text { (1999) }\end{array}$ & Timeliness & & $\begin{array}{l}\text { Redress } \\
\text { Apology }\end{array}$ & Satisfaction & Services & Customers \\
\hline Davidow (2000) & $\begin{array}{l}\text { Facilitation } \\
\text { Timeliness }\end{array}$ & $\begin{array}{l}\text { Credibility } \\
\text { Attentiveness }\end{array}$ & $\begin{array}{l}\text { Apology } \\
\text { Redress }\end{array}$ & $\begin{array}{l}\text { Satisfaction } \\
\text { Word-of-mouth } \\
\text { Repurchase } \\
\text { intentions } \\
\end{array}$ & Services & Customers \\
\hline Estelami (2000) & Timeliness & Attentiveness & Redress & Satisfaction & $\begin{array}{l}\text { Services and } \\
\text { products }\end{array}$ & Customers \\
\hline $\begin{array}{l}\text { McCollough, } \\
\text { Berry \& Yadav } \\
(2000)\end{array}$ & & Attentiveness & Redress & Satisfaction & Service & Customers \\
\hline Davidow (2003) & $\begin{array}{l}\text { Timeliness } \\
\text { Accountability } \\
\text { Facilitation }\end{array}$ & $\begin{array}{l}\text { Personal } \\
\text { interaction }\end{array}$ & Redress & $\begin{array}{l}\text { Perceived } \\
\text { justice } \\
\text { Response } \\
\text { evaluation } \\
\text { disconfirmation } \\
\text { of expectations } \\
\text { Post } \\
\text { dissatisfaction } \\
\text { customer } \\
\text { responses }\end{array}$ & & \\
\hline $\begin{array}{l}\text { Wirt \&Mattila } \\
\text { (2004) }\end{array}$ & Timeliness & & $\begin{array}{l}\text { Discount/no } \\
\text { discount } \\
\text { Apology/no } \\
\text { apology }\end{array}$ & $\begin{array}{l}\text { Satisfaction } \\
\text { Repatronage } \\
\text { intentions } \\
\text { Word of mouth } \\
\end{array}$ & Service & Customers \\
\hline $\begin{array}{l}\text { Homburg } \\
\text { \&Fürst (2005) }\end{array}$ & $\begin{array}{l}\text { Quality of } \\
\text { process } \\
\text { guidelines }\end{array}$ & $\begin{array}{l}\text { Quality of } \\
\text { behavioural } \\
\text { guidelines }\end{array}$ & $\begin{array}{l}\text { Quality of } \\
\text { outcome } \\
\text { guidelines }\end{array}$ & $\begin{array}{l}\text { Customer } \\
\text { justice } \\
\text { Customer } \\
\text { satisfaction and } \\
\text { loyalty } \\
\end{array}$ & $\begin{array}{l}\text { Services and } \\
\text { products }\end{array}$ & $\begin{array}{l}\text { Managers } \\
\text { and } \\
\text { customers }\end{array}$ \\
\hline $\begin{array}{l}\text { Homburg, Fürst } \\
\text { \& Koschate } \\
(2010)\end{array}$ & $\begin{array}{l}\text { Quality of } \\
\text { process } \\
\text { guidelines }\end{array}$ & $\begin{array}{l}\text { Quality of } \\
\text { behavioural } \\
\text { guidelines }\end{array}$ & $\begin{array}{l}\text { Quality of } \\
\text { outcome } \\
\text { guidelines }\end{array}$ & $\begin{array}{l}\text { Perceived } \\
\text { fairness of } \\
\text { complaint } \\
\text { handling } \\
\end{array}$ & $\begin{array}{l}\text { Services and } \\
\text { products }\end{array}$ & $\begin{array}{l}\text { Managers } \\
\text { and } \\
\text { customers }\end{array}$ \\
\hline
\end{tabular}


TABLE 2

Population and sample distribution

\begin{tabular}{|c|c|c|c|c|c|c|}
\hline Industry (NACE) & $\begin{array}{l}\text { Number of } \\
\text { companies in } \\
\text { the population } \\
\text { (\%) }\end{array}$ & $\begin{array}{l}\text { Number of } \\
\text { companies in } \\
\text { the sample } \\
(\%)\end{array}$ & $\begin{array}{l}\text { Proportion } \\
\text { test }\end{array}$ & \begin{tabular}{|c} 
Average \\
employee \\
number of \\
companies in the \\
population \\
(std. dev.)
\end{tabular} & $\begin{array}{c}\text { Average } \\
\text { employee } \\
\text { number of } \\
\text { companies in } \\
\text { the sample } \\
\text { (std. dev.) }\end{array}$ & $\begin{array}{c}\text { Means } \\
\text { difference } \\
\text { test }\end{array}$ \\
\hline $\begin{array}{l}\text { Food, drink and tobacco industry }(10, \\
11,12)\end{array}$ & $\begin{array}{c}599 \\
(23.62 \%) \\
\end{array}$ & $\begin{array}{c}30 \\
(21.43 \%)\end{array}$ & -.63 & $\begin{array}{c}233 \\
(546)\end{array}$ & $\begin{array}{c}247 \\
(324)\end{array}$ & .30 \\
\hline $\begin{array}{l}\text { Textile, clothing, leather and footwear } \\
\text { industry }(13,14,15)\end{array}$ & $\begin{array}{c}215 \\
(8.48 \%)\end{array}$ & $\begin{array}{c}12 \\
(8.57 \%)\end{array}$ & .04 & $\begin{array}{c}146 \\
(211)\end{array}$ & $\begin{array}{c}195 \\
(372)\end{array}$ & .80 \\
\hline $\begin{array}{l}\text { Paper, edition, graphic arts and } \\
\text { reproduction industry }(17,18)\end{array}$ & $\begin{array}{c}235 \\
(9.27 \%) \\
\end{array}$ & $\begin{array}{c}19 \\
(13.57 \%) \\
\end{array}$ & 1.49 & $\begin{array}{c}142 \\
(154) \\
\end{array}$ & $\begin{array}{c}141 \\
(177) \\
\end{array}$ & -.03 \\
\hline $\begin{array}{l}\text { Chemical, rubber and plastics industry } \\
(20,21,22)\end{array}$ & $\begin{array}{c}747 \\
(29.46 \%) \\
\end{array}$ & $\begin{array}{c}32 \\
(22.86 \%) \\
\end{array}$ & -1.86 & $\begin{array}{c}232 \\
(507) \\
\end{array}$ & $\begin{array}{c}490^{*} \\
(1575) \\
\end{array}$ & $2.64^{*}$ \\
\hline $\begin{array}{l}\text { Electrical, electronic and optical material } \\
\text { and equipment industry }(26,27)\end{array}$ & $\begin{array}{c}288 \\
(11.36 \%) \\
\end{array}$ & $\begin{array}{c}20 \\
(14.29 \%) \\
\end{array}$ & .99 & $\begin{array}{c}251 \\
(557)\end{array}$ & $\begin{array}{c}158 \\
(130)\end{array}$ & -.75 \\
\hline Transportation Equipment (29) & $\begin{array}{c}263 \\
(10.37 \%) \\
\end{array}$ & $\begin{array}{c}13 \\
(9.29 \%)\end{array}$ & -.44 & $\begin{array}{c}497 \\
(1.356)\end{array}$ & $\begin{array}{c}204 \\
(208)\end{array}$ & -.84 \\
\hline Other manufacturing industries $(31,32)$ & $\begin{array}{c}189 \\
(7.45 \%) \\
\end{array}$ & $\begin{array}{c}14 \\
(10.00 \%) \\
\end{array}$ & 1.00 & $\begin{array}{c}145 \\
(185) \\
\end{array}$ & $\begin{array}{c}241 \\
(281) \\
\end{array}$ & 1.27 \\
\hline Total & $\begin{array}{c}2536 \\
(100.00 \%)\end{array}$ & $\begin{array}{c}140 \\
(100.00 \%)\end{array}$ & & $\begin{array}{c}240 \\
(624)\end{array}$ & $\begin{array}{c}262 \\
(771)\end{array}$ & .39 \\
\hline
\end{tabular}

Level of significance: ${ }^{*} \mathrm{p}<.05$. 
TABLE 3

\section{Construct measurement}

\begin{tabular}{|c|c|c|c|c|}
\hline Construct & Indicators & Mean & $\begin{array}{l}\text { Stand. } \\
\text { Dev. }\end{array}$ & $\begin{array}{l}\text { Weights/ } \\
\text { Loadings }\end{array}$ \\
\hline Facilitation $^{b}$ & We provide the customer with various channels for receiving complaints. & 5.14 & 1.69 & 0.33 \\
\hline Max. corr. $=.52$ & Some of the channels are available 24 hours a day. & 4.61 & 2.45 & 0.21 \\
\hline $\begin{array}{l}\text { Max. VIF }=1.63 \\
(\mathrm{~F})\end{array}$ & $\begin{array}{l}\text { We inform customers about where, how and to whom they should make the } \\
\text { complaint. }\end{array}$ & 5.21 & 1.71 & $0.67^{* *}$ \\
\hline Processing & We quickly confirm to customers when we have received the complaint. & 5.71 & 1.34 & $0.49^{* *}$ \\
\hline protocol $^{b}$ & All complaints, written or verbal, are recorded in the computer system. & 5.84 & 1.53 & 0.02 \\
\hline Max. corr. $=.69$ & All the complaints are categorised and classified according to their origin and the & 5.27 & 1.73 & 0.06 \\
\hline Max. VIF=2.25 & severity of the problem. & 6.04 & 1.27 & 0.18 \\
\hline$(\mathrm{F})$ & $\begin{array}{l}\text { As soon as a complaint is received, we assign a person responsible for handling it. } \\
\text { Complaints are rapidly commented on and dealt with. }\end{array}$ & 6.12 & 1.15 & $0.51^{* *}$ \\
\hline $\begin{array}{c}\text { Customer } \\
\text { participation } \\
\text { in the process } \\
\mathrm{CR}=.97 \\
\mathrm{AVE}=.93 \\
(\mathrm{R})\end{array}$ & $\begin{array}{l}\text { We allow the customer to explain the complaint. } \\
\text { We give customers the chance to set out all the details. } \\
\text { We listen to their point of view about their problem. }\end{array}$ & $\begin{array}{l}6.24 \\
6.34 \\
6.38\end{array}$ & $\begin{array}{l}1.03 \\
0.98 \\
0.95\end{array}$ & $\begin{array}{l}0.95^{* *} \\
0.98^{* *} \\
0.95^{* *}\end{array}$ \\
\hline $\begin{array}{c}\text { Customer } \\
\text { participation } \\
\text { in the solution } \\
\mathrm{CR}=.90 \\
\mathrm{AVE}=.76 \\
(\mathrm{R})\end{array}$ & $\begin{array}{l}\text { When providing the solution, we are concerned with customer requirements. } \\
\text { We ask the customer for possible solutions. } \\
\text { Company and customer work together to find a solution to the complaint. }\end{array}$ & $\begin{array}{l}6.05 \\
5.61 \\
5.56\end{array}$ & $\begin{array}{l}1.13 \\
1.46 \\
1.47\end{array}$ & $\begin{array}{l}0.87^{* *} \\
0.92^{* *} \\
0.82^{* *}\end{array}$ \\
\hline $\begin{array}{l}\text { Interpersonal } \\
\text { treatment }\end{array}$ & $\begin{array}{l}\text { The frontline employee displays polite treatment with the customer when the latter } \\
\text { formulates complaints. }\end{array}$ & 6.34 & 0.76 & $0.90^{* *}$ \\
\hline $\mathrm{CR}=.92$ & Employees are very interested in the customer’s problem. & 6.35 & 0.83 & $0.92^{* *}$ \\
\hline $\begin{array}{l}\mathrm{AVE}=.80 \\
(\mathrm{R})\end{array}$ & $\begin{array}{l}\text { Employees who are responsible for complaint management have empathy skills } \\
\text { with the customer. }\end{array}$ & 6.20 & 0.79 & $0.87^{* *}$ \\
\hline $\begin{array}{l}\text { Explanation } \\
\mathrm{CR}=.94\end{array}$ & $\begin{array}{l}\text { We provide our customer with a reasonable explanation about the causes of the } \\
\text { problem. }\end{array}$ & 6.21 & 0.90 & $0.93^{* *}$ \\
\hline $\begin{array}{l}\mathrm{AVE}=.88 \\
\quad(\mathrm{R})\end{array}$ & $\begin{array}{l}\text { We provide a precise answer to all the questions raised in the customer's } \\
\text { complaint. }\end{array}$ & 6.19 & 0.84 & $0.95^{* *}$ \\
\hline Apology & We always admit our fault to the customer if the complaint is reasonable. & 6.05 & 1.18 & $0.86^{* *}$ \\
\hline $\begin{array}{c}\mathrm{CR}=.87 \\
\mathrm{AVE}=.69\end{array}$ & $\begin{array}{l}\text { If any failure occurs, we admit our responsibility and we let the customer know } \\
\text { about it. }\end{array}$ & 6.17 & 1.06 & $0.90^{* *}$ \\
\hline$(\mathrm{R})$ & Apart from solving the problem, we always apologise to our customer. & 6.05 & 1.33 & $0.71^{* *}$ \\
\hline $\begin{array}{l}\text { Redress } \\
\mathrm{CR}=.87 \\
\mathrm{AVE}=.77 \\
\quad(\mathrm{R})\end{array}$ & $\begin{array}{l}\text { Beyond the solution, we offer our customer a direct economic redress. } \\
\text { Beyond the solution, we offer our customer an indirect economic redress. }\end{array}$ & $\begin{array}{l}4.04 \\
2.88\end{array}$ & $\begin{array}{l}1.93 \\
1.97\end{array}$ & $\begin{array}{l}0.91^{* *} \\
0.84^{* *}\end{array}$ \\
\hline $\begin{array}{c}\text { Organic } \\
\text { approach }^{\mathrm{c}} \\
\text { Max. corr. }=.52 \\
\text { Max. VIF }=1.81 \\
(\mathrm{~F})\end{array}$ & $\begin{array}{l}\text { Training } \\
\text { Empowerment } \\
\text { Extra-role behaviour }\end{array}$ & $\begin{array}{l}- \\
-\end{array}$ & $\begin{array}{l}- \\
- \\
-\end{array}$ & $\begin{array}{l}0.47 * * \\
0.38 * * \\
0.41 * *\end{array}$ \\
\hline $\begin{array}{c}\text { Justice in } \\
\text { solutions } \\
\mathrm{CR}=.90 \\
\mathrm{AVE}=.74 \\
(\mathrm{R})\end{array}$ & $\begin{array}{l}\text { We provide a solution to the complaint according to customer's needs. } \\
\text { The solutions given to customers are fair. } \\
\text { We are working to provide a satisfactory solution. }\end{array}$ & $\begin{array}{l}5.99 \\
6.01 \\
6.41\end{array}$ & $\begin{array}{l}0.96 \\
1.00 \\
0.83\end{array}$ & $\begin{array}{l}0.84^{* *} \\
0.87^{* *} \\
0.87^{* *}\end{array}$ \\
\hline $\begin{array}{c}\text { Customer } \\
\text { satisfaction } \\
\mathrm{CR}=.93 \\
\mathrm{AVE}=.78 \\
(\mathrm{R})\end{array}$ & $\begin{array}{l}\text { Satisfaction with the procedure for filing complaints. } \\
\text { Satisfaction with treatment received. } \\
\text { Satisfaction with the solution provided. } \\
\text { Satisfaction with the complaint resolution system. }\end{array}$ & $\begin{array}{l}5.55 \\
5.91 \\
5.75 \\
5.64\end{array}$ & $\begin{array}{l}0.94 \\
0.91 \\
0.90 \\
0.92\end{array}$ & $\begin{array}{l}0.83^{* *} \\
0.89^{* *} \\
0.88^{* *} \\
0.93^{* *}\end{array}$ \\
\hline $\begin{array}{c}\text { Company } \\
\text { satisfaction }\end{array}$ & Level of overall satisfaction of the company with the complaint system. & 5.79 & 0.86 & 1.00 \\
\hline
\end{tabular}

${ }^{a}$ For reflective indicators (R) the factor loading is offered and for formative indicators $(\mathrm{F})$ the weight is the value being examined.

${ }^{\mathrm{b}}$ Formative indicators with non-significant weights have factor loadings close to 0.5, hence they are retained in the measurement model.

${ }^{c}$ All the first-order components of the organic approach (training, empowerment and extra-role behaviours) are measured with three reflective indicators.

Level of significance: ${ }^{* *} \mathrm{p}<.01 ;{ }^{*} \mathrm{p}<.05$ (one-tailed test). 
TABLE 4

Correlation matrix and discriminant validity

\begin{tabular}{|c|c|c|c|c|c|c|c|c|c|c|c|c|}
\hline & 1 & 2 & 3 & 4 & 5 & 6 & 7 & 8 & 9 & 10 & 11 & 12 \\
\hline 1. Facilitation & n.a & n.a & n.a & n.a & n.a & n.a & n.a & n.a & n.a & n.a & n.a & n.a \\
\hline 2. Processing protocol & .465 & n.a & n.a & n.a & n.a & n.a & n.a & n.a & n.a & n.a & n.a & n.a \\
\hline 3. Customer participation process & 0.547 & 0.706 & 0.963 & 0.625 & 0.699 & 0.664 & 0.708 & 0.071 & 0.560 & 0.814 & 0.571 & 0.312 \\
\hline 4. Customer participation solution & 0.417 & 0.560 & 0.573 & 0.872 & 0.496 & 0.560 & 0.523 & 0.163 & 0.529 & 0.666 & 0.630 & 0.343 \\
\hline 5. Interpersonal treatment & 0.369 & 0.579 & 0.644 & 0.440 & 0.896 & 0.819 & 0.724 & 0.080 & 0.540 & 0.804 & 0.621 & 0.436 \\
\hline 6. Explanation & 0.387 & 0.643 & 0.605 & 0.485 & 0.717 & 0.940 & 0.665 & 0.170 & 0.642 & 0.862 & 0.695 & 0.462 \\
\hline 7. Apology & 0.475 & 0.645 & 0.620 & 0.434 & 0.596 & 0.561 & 0.828 & 0.286 & 0.587 & 0.840 & 0.682 & 0.480 \\
\hline 8. Redress & 0.177 & 0.023 & -0.048 & 0.128 & 0.068 & 0.136 & 0.208 & 0.877 & 0.264 & 0.124 & 0.152 & 0.195 \\
\hline 9. Organic approach & 0.432 & 0.407 & 0.514 & 0.460 & 0.474 & 0.564 & 0.494 & 0.206 & 0.701 & 0.664 & 0.550 & 0.356 \\
\hline 10. Justice in solutions & 0.452 & 0.642 & 0.728 & 0.567 & 0.689 & 0.733 & 0.685 & 0.012 & 0.568 & 0.862 & 0.795 & 0.536 \\
\hline 11. Customer satisfaction & 0.406 & 0.537 & 0.534 & 0.559 & 0.558 & 0.616 & 0.577 & 0.122 & 0.491 & 0.691 & 0.884 & 0.616 \\
\hline 12. Company satisfaction & 0.275 & 0.379 & 0.306 & 0.321 & 0.412 & 0.431 & 0.427 & 0.170 & 0.332 & 0.489 & 0.587 & 1.000 \\
\hline
\end{tabular}

Notes: The elements below the diagonal correspond to the correlations between each pair of constructs. On the diagonal is the square root of the AVE. The elements above the diagonal correspond to the HTMT ratio for each pair of constructs. n.a.: not applicable to formative constructs. 
TABLE 5

Direct, indirect and total effects of the structural model relationships

\begin{tabular}{|c|c|c|c|c|c|c|c|c|c|}
\hline \multirow[b]{3}{*}{ Predictors } & \multicolumn{9}{|c|}{ Dependent variables } \\
\hline & \multicolumn{3}{|c|}{ Justice in solutions } & \multicolumn{3}{|c|}{ Customer satisfaction } & \multicolumn{3}{|c|}{ Company satisfaction } \\
\hline & $\begin{array}{l}\text { Direct } \\
\text { effects }\end{array}$ & $\begin{array}{l}\text { Indirect } \\
\text { effects }\end{array}$ & $\begin{array}{c}\text { Total } \\
\text { effects }\end{array}$ & $\begin{array}{l}\text { Direct } \\
\text { effects }\end{array}$ & $\begin{array}{c}\text { Indirect } \\
\text { effects }\end{array}$ & $\begin{array}{c}\text { Total } \\
\text { effects }\end{array}$ & $\begin{array}{l}\text { Direct } \\
\text { effects }\end{array}$ & $\begin{array}{c}\text { Indirect } \\
\text { effects }\end{array}$ & $\begin{array}{r}\text { Total } \\
\text { effects }\end{array}$ \\
\hline Facilitation & $0.00\left(\mathrm{H}_{1}\right)$ & & 0.00 & 0.05 & 0.00 & 0.05 & & 0.03 & 0.03 \\
\hline Processing protocol & $-0.06\left(\mathrm{H}_{2}\right)$ & & -0.06 & 0.01 & -0.02 & -0.01 & & -0.01 & -0.01 \\
\hline Customer participation in the process & $0.22^{*}\left(\mathrm{H}_{3}\right)$ & & $0.22^{*}$ & -0.12 & $0.08^{*}$ & -0.04 & & -0.02 & -0.02 \\
\hline Customer participation in the solution & $0.14^{*}\left(\mathrm{H}_{4}\right)$ & & $0.14^{*}$ & $0.22^{*}$ & $0.05^{*}$ & $0.27^{*}$ & & $0.15^{*}$ & $0.15^{*}$ \\
\hline Interpersonal treatment & $0.10\left(\mathrm{H}_{5}\right)$ & & 0.10 & 0.06 & 0.04 & 0.10 & & 0.05 & 0.05 \\
\hline Explanation & $0.32^{* *}\left(\mathrm{H}_{6}\right)$ & & $0.32^{* *}$ & 0.15 & $0.11^{*}$ & $0.26^{* *}$ & & $0.15^{* *}$ & $0.15^{* *}$ \\
\hline Apology & $0.28^{* *}\left(\mathrm{H}_{7}\right)$ & & $0.28^{* *}$ & 0.14 & $0.10^{* *}$ & $0.24^{* *}$ & & $0.13^{*}$ & $0.13^{*}$ \\
\hline Redress & $-0.12^{*}\left(\mathrm{H}_{8}\right)$ & & $-0.12^{*}$ & 0.01 & $-0.04^{*}$ & -0.03 & & -0.02 & -0.02 \\
\hline Justice in solutions & & & & $0.36^{* *}$ & & $0.36^{* *}$ & & $0.20^{* *}$ & $0.20^{* * *}$ \\
\hline Customer satisfaction & & & & & & & $0.56^{* *}$ & & $0.56^{* * *}$ \\
\hline Organic approach & 0.08 & & 0.08 & 0.04 & 0.03 & 0.07 & 0.06 & 0.04 & 0.10 \\
\hline $\mathrm{R}^{2}$ & \multicolumn{3}{|c|}{$73.3 \%$} & \multicolumn{3}{|c|}{$55.8 \%$} & \multicolumn{3}{|c|}{$34.7 \%$} \\
\hline
\end{tabular}

Level of significance: $* * \mathrm{p}<.01 ; * \mathrm{p}<.05$ (one-tailed test). 